\title{
Different seasonality of pelagic and benthic Thaumarchaeota in the North Sea
}

\author{
N. J. Bale ${ }^{1, *}$, L. Villanueva ${ }^{1, *}$, E. C. Hopmans ${ }^{1}$, S. Schouten ${ }^{1}$, and J. S. Sinninghe Damsté ${ }^{1}$ \\ ${ }^{1}$ NIOZ Royal Netherlands Institute for Sea Research, Department of Marine Organic Biogeochemistry, P.O. Box 59, \\ 179AB Den Burg, the Netherlands \\ *These authors contributed equally to this work.
}

Correspondence to: N. J. Bale (nicole.bale@nioz.nl)

Received: 17 July 2013 - Published in Biogeosciences Discuss.: 2 August 2013

Revised: 30 September 2013 - Accepted: 11 October 2013 - Published: 12 November 2013

\begin{abstract}
We have examined the spatial and seasonal distribution of Thaumarchaeota in the water column and sediment of the southern North Sea using the specific intact polar lipid (IPL) hexose-phosphohexose (HPH) crenarchaeol, as well as thaumarchaeotal 16S rRNA gene abundances and expression. In the water column, a higher abundance of Thaumarchaeota was observed in the winter season than in the summer, which is in agreement with previous studies, but this was not the case in the sediment where Thaumarchaeota were most abundant in spring and summer. This observation corresponds well with the idea that ammonia availability is a key factor in thaumarchaeotal niche determination. In the surface waters of the southern North Sea, we observed a spatial variability in HPH crenarchaeol, thaumarchaeotal $16 \mathrm{~S}$ rRNA gene abundance and transcriptional activity that corresponded well with the different water masses present. In bottom waters, a clear differentiation based on water masses was not observed; instead, we suggest that observed differences in thaumarchaeotal abundance with depth may be related to resuspension from the sediment. This could be due to suspension of benthic Thaumarchaeota to the water column or due to delivery of e.g. resuspended sediment or ammonium to the water column, which could be utilized by pelagic Thaumarchaeota. This study has shown that the seasonality of Thaumarchaeota in water and sediment is different and highlights the importance of water masses, currents and sedimentary processes in determining the spatial abundance of Thaumarchaeota in the southern North Sea.
\end{abstract}

\section{Introduction}

Nitrogen is an essential element for all life and in the marine environment is a key nutrient which can be a limiting factor for primary production (Gruber, 2008). Our understanding of the marine nitrogen cycle has been enhanced in recent years by new discoveries relating to the discovery of ammonium-oxidizing Archaea (AOA) (Francis et al., 2007; Könneke et al., 2005; Wuchter et al., 2006), recently reclassified in the novel phylum Thaumarchaeota (BrochierArmanet et al., 2008). AOA oxidize ammonia aerobically to nitrite, the first and rate-determining step of the nitrification process. Their physiology, along with their high abundance and global prevalence, make them biogeochemically important microorganisms in the marine environment (Herndl et al., 2005; Karner et al., 2001). As yet, their metabolism have not been fully elucidated and there are various pieces of evidence that Thaumarchaeota may be autotrophs, mixotrophs or heterotrophs (Agogue et al., 2008; Alonso-Sáez et al., 2012; Hansman et al., 2009; Ingalls et al., 2006), which can potentially use as a carbon source bicarbonate (Könneke et al., 2005; Pearson et al., 2001; Pitcher et al., 2011b; Wuchter et al., 2003), amino acids (Ouverney and Fuhrman, 2000; Teira et al., 2004, 2006) and urea (Alonso-Sáez et al., 2012).

A number of studies have shown that in coastal waters there are higher numbers of Thaumarchaeota in winter than in summer (Galand et al., 2010; Herfort et al., 2007; Wuchter et al., 2006). These studies have proposed a number of environmental factors as causes for the Thaumarchaeotal seasonality: competition with phytoplankton and/or bacteria for ammonia, light, temperature and the concentration of the 
inorganic nutrients. Furthermore, the study of pelagic Thaumarchaeota has revealed high levels of spatial variability, which has been suggested to be associated with, alongside those variables described above, the dissolved oxygen (DO) concentration, the presence of organic substrates, salinity and sulfide concentration (Agogue et al., 2008; Beman et al., 2012; Coolen et al., 2007; Erguder et al., 2009; Francis et al., 2007; Herfort et al., 2007; Könneke et al., 2005; Park et al., 2010). While the afore mentioned studies have concentrated on the spatial and temporal distribution of Thaumarchaeota in the water column, their activity, diversity and physiology in marine sediments and the relationship between these two settings is less well constrained. Suggested environmental controls of benthic thaumarchaeotal abundance and activity in estuarine and marine sediments include the presence of sulfide, salinity, DO levels, $\mathrm{pH}$, the availability of phosphorus, temperature and primary production (Bernhard et al., 2010; Dang et al., 2013; Erguder et al., 2009; Mosier and Francis, 2008; Sahan and Muyzer, 2008; Sakami, 2012).

A specific set of cell membrane-derived intact polar lipids (IPLs) with glycerol dialkyl glycerol tetraether (GDGT) core structures, in particular crenarchaeol, have been utilized as biomarkers for Thaumarchaeota in the natural environment (Pitcher et al., 2011a, b) and have been described in several thaumarchaeotal enrichment cultures (see Table 4 in Schouten et al., 2013). Upon cell death the polar head groups of IPLs are lost relatively quickly (White et al., 1979), while the remaining core-lipids can be preserved over geological timescales (e.g. Jenkyns et al., 2012). The hexosephosphohexose (HPH) crenarchaeol (Schouten et al., 2008) has been applied in several studies as a biomarker for living or recently living Thaumarchaeota due to the relatively labile nature of the phosphoester bond (Buckles et al., 2013; Lengger et al., 2012; Pitcher et al., 2011a, b). For example, Pitcher et al. (2011b) found that HPH crenarchaeol and Thaumarchaeota abundance (based on 16S rRNA and ammonia monooxygenase, amoA gene quantification) in suspended particulate matter in the North Sea correlated well, validating this combined marker approach to assess the abundance of living AOA. A similar observation was made by Pitcher et al. (2011a) for AOA in the Arabian Sea oxygen minimum zone.

Here we studied the seasonality and distribution of Thaumarchaeota in the southern North Sea. The North Sea is a continental shelf sea, semi-enclosed from the Atlantic Ocean by the British Isles. Continental shelf seas are areas of key importance in global biogeochemical cycles and are the part of the global marine sphere most impacted by human activity (Gattuso et al., 1998). The southern North Sea (Fig. 1) is shallow (50 $\mathrm{m}$ at maximum with some deeper exceptions) and is bounded in the north by the shallow Dogger Bank, characterized by sandy sediment, and in the east by the Dutch coast which is also sandy and shallow. Between them there is a depression known as the Oyster Grounds (Fig. 1) which is a temporary deposition center for sediment (Van Raaphorst

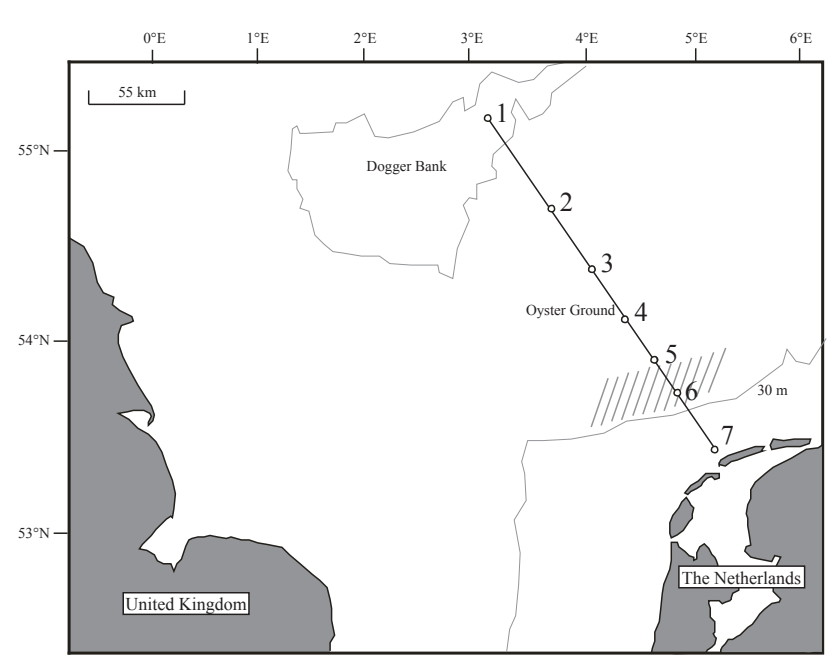

Fig. 1. Map of the southern North Sea showing the study site. Stations are labeled 1-7. Approximate bathometry at $30 \mathrm{~m}$ illustrated with gray line and approximate area of the Frisian Front indicated with hatched area. Adapted from map in Weston et al. (2008).

et al., 1998) and plays an important role in the carbon and nitrogen cycle in the region (Weston et al., 2008). At the southeastern edge of the Oyster Grounds there is an area called the Frisian Front, a transition zone between the shallow Dutch coast and the deeper Oyster Grounds (approximate area of the Frisian Front indicated with hatched area in Fig. 1). Here, particulate matter from the sandy Southern Bight is sedimented resulting in organic-rich, muddy sediment which supports high levels of benthic fauna (Creutzberg, 1986; Van Raaphorst et al., 1992). Previous studies in the North Sea mostly using core lipids and thaumarchaeotal 16S rRNA gene abundance, found that Thaumarchaeota in the water column were most abundant in winter (Herfort et al., 2007; Pitcher et al., 2011b; Wuchter et al., 2006). Furthermore, it was found that there was spatial variability in their distribution in the southern North Sea (Herfort et al., 2007). We investigated the seasonality and spatial distribution of Thaumarchaeota in both the water column as well as sediments in the southern North Sea using, in contrast to Herfort et al. (2007), specific IPLs. To support our interpretations we also determined thaumarchaeotal DNA abundances and diversity as well as transcriptional activity (gene expression, RNA) at selected stations and seasons.

\section{Material and methods}

\subsection{Sampling locations}

Sampling was carried out during four cruises onboard the R/V Pelagia; in late November 2010, February 2011, May 2011 and August 2011. The cruises followed the Terschelling transect and sampling occurred at seven stations, starting at 
the Dogger Bank, $235 \mathrm{~km}$ from the Dutch coast, and finished approximately $5 \mathrm{~km}$ from the island of Terschelling (Fig. 1). Three of the seven stations (1,4 and 7) were sampled for sediment characteristics, i.e. porewater, grain size and total organic carbon (TOC).

\subsection{Measurement of chemical and physical parameters}

Temperature and salinity were measured using a Sea-Bird SBE911+ conductivity-temperature-depth (CTD) system. A rosette sampler containing $24 \times 12 \mathrm{~L}$ Niskin bottles was attached to the CTD. Samples for sea water nutrient analysis were taken from the Niskin bottles into polypropylene bottles and ca. $5 \mathrm{~mL}$ samples were filtered over $0.45 \mu \mathrm{m} 25 \mathrm{~mm}$ Acrodisc HT Tuffryn Membrane syringe filters (Pall Corporation, Washington) into pre-rinsed pony vials. The samples were sub-sampled in a $5 \mathrm{~mL}$ polyethylene vial. Samples analyzed onboard were stored dark at $4{ }^{\circ} \mathrm{C}$ and were analyzed within $18 \mathrm{~h}$ on a QuAAtro autoanalyzer. Samples not analyzed onboard but at the $\mathrm{NIOZ}$ were stored at $-18^{\circ} \mathrm{C}$ except those for silicate analysis, which were stored at $4{ }^{\circ} \mathrm{C}$. Porewater collection was carried out in a thermally controlled container maintained at the water temperature measured by CTD near to the sediment surface. Cores were collected with a multicorer and sliced hydraulically. Porewater was extracted from $25 \mathrm{~mm}$ sediment slices from 0 to $1 \mathrm{~cm}$ depth by centrifugation (approx. $4000 \mathrm{~g}, 5 \mathrm{~min}$ through a $0.45 \mu \mathrm{m} 25 \mathrm{~mm}$ Acrodisc HT Tuffryn Membrane syringe filter) and stored in pre-rinsed pony vials. The standard deviation of samples measured between different runs was $\mathrm{PO}_{4} 0.007 \mu \mathrm{M} ; \mathrm{NH}_{4}$ $0.013 \mu \mathrm{M} ; \mathrm{NO}_{3}+\mathrm{NO}_{2} 0.041 \mu \mathrm{M}$; and $\mathrm{NO}_{2} 0.005 \mu \mathrm{M}$.

\subsection{Intact polar lipid sample collection}

Two McLane in situ pumps (McLane Laboratories Inc., Falmouth) were used to collect suspended particulate matter (SPM) from the water column for IPL analysis. They were deployed at two depths, near bottom (2-3 $\mathrm{m}$ above the seafloor, hereafter called bottom water) and near the water surface $(2-3 \mathrm{~m}$ below the surface, hereafter called surface water). They pumped between 30 and $200 \mathrm{~L}$ with a cut-off at a pre-programmed pressure threshold and the SPM was collected on pre-ashed $0.7 \mu \mathrm{m} \mathrm{GF/F} \mathrm{filters} \mathrm{(Pall} \mathrm{Corporation,}$ Washington) and immediately frozen at $-80^{\circ} \mathrm{C}$. Despite the nominal pore size of the filters being larger than thaumarchaeotal cells ( $\sim 0.2 \mu \mathrm{m}$; Könneke et al., 2005$)$, testing of the sampling methodology found minimal loss of cells though the filter, most probably due to clogging of pores with particulate matter in the turbid North Sea waters (Herfort et al., 2007; Bale et al., unpub. results). Sediment was collected at each station in $10 \mathrm{~cm}$ diameter, $60 \mathrm{~cm}$ length multicores or push cores into boxcores. The cores were sliced into $1 \mathrm{~cm}$ slices using the hydraulic slicer or a manual slicer and each slice was stored separately in a geochemical bag and immediately frozen at $-80^{\circ} \mathrm{C}$. Upon arrival in the laboratory, fil- ters and sediment samples for lipid analysis were stored at $-40^{\circ} \mathrm{C}$ until freeze drying and extraction. For this study we analyzed the $0-1 \mathrm{~cm}$ (surface sediment) slice.

\subsection{Intact polar lipid extraction and analysis}

After freeze drying, sediment samples were homogenized and GF/F filters were cut into small pieces. The extractions were carried out using a modified Bligh Dyer extraction (Pitcher et al., 2011a). A known volume of single-phase solvent mixture of methanol $(\mathrm{MeOH})$ : dichloromethane $(\mathrm{DCM})$ : phosphate buffer $(2: 1: 0.8, \mathrm{v}: \mathrm{v}: \mathrm{v})$ was added to the sample in a glass centrifuge tube and placed in an ultrasonic bath for $10 \mathrm{~min}$. The extract and residue were separated by centrifuging at $1000 \times g$ for $5 \mathrm{~min}$ and the solvent mixture collected in a separate flask, then this was repeated three times. DCM and phosphate buffer were added to the singlephase extract to give a new ratio of $\mathrm{MeOH}: \mathrm{DCM}$ : phosphate buffer $(1: 1: 0.9, \mathrm{v}: \mathrm{v}: \mathrm{v})$, and to induce phase separation. The extract was centrifuged at $1000 \times g$ for $5 \mathrm{~min}$. The DCM phase was collected in a round-bottom flask and the $\mathrm{MeOH}$ : phosphate buffer phase was washed two additional times with DCM. The combined DCM phases were reduced under rotary vacuum and evaporated to dryness under a stream of $\mathrm{N}_{2}$. Analysis was carried out as described by Sturt et al. (2004) with modifications on an Agilent (Palo-Alto, CA, USA) 1100 series LC equipped with a thermostated autoinjector, coupled to a Thermo TSQ Quantum EM triple quadrupole mass spectrometer equipped with an Ion Max source with ESI probe. Separation was achieved on a LiChrospher diol column $(250 \times 2.1 \mathrm{~mm}, 5 \mu \mathrm{m}$ particles; Alltech) maintained at $30^{\circ} \mathrm{C}$. For details of gradient, source parameter optimization and ESI setting see Schouten et al. (2008). The selected reaction monitoring (SRM) for the crenarchaeol-based IPLs method has been previously described (Pitcher et al., 2011a). As described in Pitcher et al. (2011b) crenarchaeol-based IPLs were quantified as the integrated IPL peak area response (response units, r.u.) per liter or per gram of sediment.

\subsection{Nucleic acid sample collection}

Water samples (ca. 2L) recovered from the CTD rosette Niskin bottles were filtered onboard for DNA and RNA analysis through Sterivex ${ }^{\mathrm{TM}}$-GP filtering unit $(0.22 \mu \mathrm{m}$ pore size $)$ via a peristaltic pump (Millipore corporation, Billerica, MA). The handling/filtering time was reduced to the minimum and water samples were kept on ice during the filtration process. Sterivex filters were preserved with $2 \mathrm{~mL}$ RNAprotect Bacteria Reagent (Qiagen Inc, Valencia, CA, USA) to prevent RNA degradation and immediately stored at $-20^{\circ} \mathrm{C}$. Sediment top cores were sampled at the same time and under the same conditions as for lipid analysis and stored at $-80^{\circ} \mathrm{C}$. For this study we analyzed the $0-1 \mathrm{~cm}$ (surface sediment) slice. 


\subsection{Nucleic acid (RNA and DNA) extraction}

Sterivex filters were defrosted on ice and the RNAprotect bacteria solution (Qiagen Inc, Valencia, CA, USA) was ejected from the cartridge through an inlet with a syringe. The Sterivex filter cartridge was cut open and the filter removed from the cartridge and cut into small pieces with a sterile razor blade. Filter sections were lysed by beadbeating with $1 \mathrm{~g}$ of sterile $0.1 \mathrm{~mm}$ zirconium beads (Biospec, Bartlesville, OK, USA) in $5 \mathrm{~mL}$ cold RLT buffer (Qiagen) plus $50 \mu \mathrm{L} \beta$-mercaptoethanol for $10 \mathrm{~min}$. Clear lysate was loaded in AllPrep DNA/RNA Mini kit (Qiagen) columns following manufacturer's instructions. DNA and RNA extracts were obtained with this kit. DNA and RNA from sediment top cores were extracted by using DNA or RNA PowerSoil ${ }^{\circledR}$ Total Isolation Kit, respectively (Mo Bio Laboratories, Inc., Carlsbad, CA, USA). Nucleic acid concentrations were quantified spectrophotometrically (Nanodrop, Thermo Scientific, Wilmington, DE, USA) and checked by agarose gel electrophoresis for quality. Extracts were kept frozen at $-80^{\circ} \mathrm{C}$. The RNA extracts were treated with RNase-Free DNase (Turbo DNA-free ${ }^{\mathrm{TM}}$, Ambion Inc., Austin, TX, USA). RNA quality and concentration were estimated by the Experion RNA StdSens Analysis Kit (Bio-Rad Laboratories, Hercules, CA, USA). Potential DNA contamination was checked by PCR using RNA as a template.

\subsection{Reverse transcription (RT)-PCR}

Reverse transcription (RT) was performed with an Enhanced Avian First Strand synthesis kit (Sigma-Aldrich Co., St Louis, MO, USA) as described previously (Holmes et al., 2004) using random nonamers. Two negative controls lacking reverse transcriptase or RNA were included. PCR reactions were performed as described above to confirm the transcription to cDNA and the negative controls using the RT reaction as a template.

\subsection{PCR amplification and cloning}

Amplification of archaeal 16S rRNA genes was performed using the universal primer combination 21F/958R (DeLong, 1992) followed by a nested reaction using the primer Parch519F/Arc915R for general Archaea (Pitcher et al., 2011a). PCR reaction mixture was the following (final concentration): Q-solution (PCR additive, Qiagen, Valencia, CA, USA) $1 \times$; PCR buffer $1 \times$; BSA $\left(200 \mu \mathrm{gL}^{-1}\right)$; dNTPs $(20 \mu \mathrm{M})$; primers $\left(0.2 \mathrm{pmol} \mu \mathrm{L}^{-1}\right) ; \mathrm{MgCl}_{2}(1.5 \mathrm{mM}) ; 1.25 \mathrm{U}$ Taq polymerase (Qiagen, Valencia, CA, USA). PCR conditions for these amplifications were the following: $95^{\circ} \mathrm{C}$, $5 \mathrm{~min} ; 35 \times\left[95^{\circ} \mathrm{C}, 1 \mathrm{~min}\right.$; Tm, $\left.1 \mathrm{~min} ; 72^{\circ} \mathrm{C}, 1 \mathrm{~min}\right]$; final extension $72^{\circ} \mathrm{C}, 5 \mathrm{~min}$. PCR products were gel purified (QIAquick gel purification kit, Qiagen) and cloned in the TOPOTA cloning ${ }^{\circledR}$ kit from Invitrogen (Carlsbad, CA, USA) and transformed in E. coli TOP10 cells following the manufac- turer's recommendations. A 96-well plate/library of recombinant plasmidic DNA was sequenced using M13R (5'-CAG GAA ACA GCT ATG AC-3') primer by Macrogen Inc. (Amsterdam, the Netherlands).

\subsection{Phylogenetic analysis}

Sequences were analyzed for the presence of chimeras using the Bellerophon tool at the GreenGenes website (http: //greengenes.lbl.gov/). The phylogenetic affiliation of the partial archaeal 16S rDNA gene sequences were compared to release 111 of the Silva SSU Ref database (http://www. arb-silva.de/; Quast et al., 2013) using the ARB software package (Ludwig et al., 2004). The partial sequences generated in this study were added to the reference tree supplied by the Silva database using the ARB Parsimony tool. Sequences were deposited in NCBI with the following accession numbers: KF361016-KF361310.

\subsection{Quantitative PCR (qPCR) analysis}

qPCR analyses were performed on a Bio-rad CFX $96^{\mathrm{TM}}$ RealTime System/C1000 thermal cycler equipped with CFX Manager ${ }^{\mathrm{TM}}$ Software. The copy numbers of thaumarchaeal 16S rRNA gene were estimated by using the thaumarchaeotal 1.1a group 16S rRNA gene primers MCGI-391F/MCGI554R (Coolen et al., 2007). All qPCR reactions were performed in triplicate with standard curves from $10^{0}$ to $10^{7}$ molecules per microliter. Standard curves were generated as described before (Pitcher et al., 2011a). Gene copies were determined in triplicate on diluted DNA extract. The reaction mixture $(25 \mu \mathrm{L})$ contained $1 \mathrm{U}$ of Pico Maxx highfidelity DNA polymerase (Stratagene, Agilent Technologies, Santa Clara, CA, USA) $2.5 \mu \mathrm{L}$ of $10 \times$ Pico Maxx PCR buffer, $2.5 \mu \mathrm{L}$ of $2.5 \mathrm{mmol} \mathrm{L}^{-1}$ of each dNTP, $0.5 \mu \mathrm{L}$ BSA

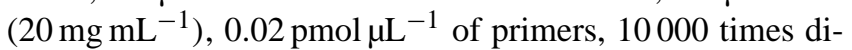
luted SYBR Green ${ }^{\circledR}$ (Invitrogen) (optimized concentration), $0.5 \mu \mathrm{L}$ of $50 \mathrm{mmol} \mathrm{L}^{-1}$ of $\mathrm{MgCl}_{2}$ and ultra-pure sterile water. All reactions were performed in $\mathrm{iCycler}_{\mathrm{iQ}} \mathrm{Q}^{\mathrm{TM}}$ 96-well plates (Bio-Rad, Hercules CA, USA) with optical tape (Bio-Rad). One $\mu \mathrm{L}$ of diluted environmental DNA was added to $24 \mu \mathrm{L}$ of mix in each well. Specificity of the reaction was tested with a gradient melting temperature assay. The cycling conditions for the qPCR reaction were the following: $95^{\circ} \mathrm{C}$, $4 \mathrm{~min} ; 40-45 \times\left[95^{\circ} \mathrm{C}, 30 \mathrm{~s}\right.$; Tm (MCGI-391F/MCGI-554R for Thaumarchaeota $16 \mathrm{~S}$ rRNA gene; $\operatorname{Tm} 61^{\circ} \mathrm{C}$, efficiency $=$ $\left.\left.90 \%, R^{2}=0.955\right), 40 \mathrm{~s} ; 72^{\circ} \mathrm{C}, 30 \mathrm{~s}\right]$; final extension $80^{\circ} \mathrm{C}$, $25 \mathrm{~s}$. Specificity for qPCR reaction was tested on agarose gel electrophoresis and with a melting curve analysis $\left(50-95^{\circ} \mathrm{C}\right.$; with a read every $0.5^{\circ} \mathrm{C}$ held for $1 \mathrm{~s}$ between each read) in order to identify unspecific PCR products such as primer dimers or fragments with unexpected fragment lengths. 


\section{Results}

\subsection{Physicochemical conditions}

Water temperature varied from 4.6 to $18.3{ }^{\circ} \mathrm{C}$ and thermal stratification was evident at stations 3 and 4 in May and stations 2-4 in August (Table 1). The salinity for stations 1-6 was between 34 and 35 practical salinity units (psu), while station 7, the most coastal station, had a salinity that ranged between 30 and $32 \mathrm{psu}$. Ammonium concentrations in the surface water ranged from 0.04 to $5.2 \mu \mathrm{M}$ and were higher or similar to bottom water concentrations (Table 1 and Fig. S1). Concentrations were seasonally highest in November and spatially at station 7 . The nitrite concentrations ranged from below the limit of detection $(0.01 \mu \mathrm{M})$ to $1.9 \mu \mathrm{M}$, with highest concentrations in November. Nitrate concentration ranged from below the limit of detection $(0.08 \mu \mathrm{M})$ to $39 \mu \mathrm{M}$, with the highest concentrations in February. The concentration of phosphate in the surface and bottom water followed a similar trend as nitrate, although the concentration was higher in August than May. Overall values ranged between 0.03 and $0.71 \mu \mathrm{M}$.

The surface sediment from both station 1 and from station 7 was composed mainly of fine and coarse sandy particles and was low in TOC $(0.03 \%)$ (Table 2). The surface sediment at station 4 was muddy sand; it contained $30 \%$ silt and clay particles and a TOC content of $0.3 \%$. Ammonium concentrations in the pore water ranged between 2.3 and $14 \mu \mathrm{M}$ and were highest in February at station 1 and in August at stations 4 and 7. Porewater nitrate was between 5 and $44 \mu \mathrm{M}$ and was also highest in February at station $1(22 \mu \mathrm{M})$, while it peaked in May at station $4(20 \mu \mathrm{M})$ and February at station $7(44 \mu \mathrm{M})$. Porewater nitrite was highest in August at all three stations and ranged between 0.2 and $2 \mu \mathrm{M}$. The concentration of phosphate in the porewater was quite constant between stations and seasons, falling in the range $0.9-1.9 \mu \mathrm{M}$ with the exception of station 1 in August when it was $3.9 \mu \mathrm{M}$.

\subsection{Hexose-phosphohexose crenarchaeol}

Hexose-phosphohexose crenarchaeol (HPH) was detected in all SPM samples as well as in the surface sediments. In the surface water, the HPH abundance was elevated (max. $3.2 \times 10^{6}$ response units (r.u.) $\mathrm{L}^{-1}$ ) at stations $3-$ 6 in November and February (Fig. 2a), while in the bottom water (Fig. 2b) it was highest at stations 4 and 6 (max. $8.6 \times 10^{6}$ r.u. $\mathrm{L}^{-1}$ ), also in November and February. In the surface sediment, the HPH abundance was always highest at station 6 except in May, when it was highest at station 5 and was generally highest in August and lowest in November (Fig. 3).
A

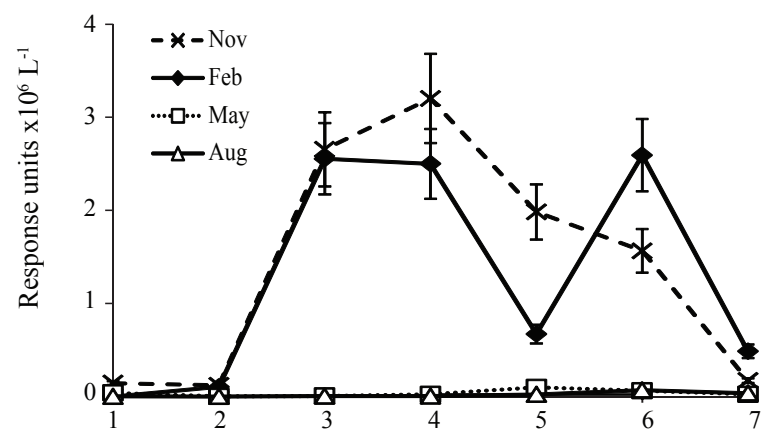

B

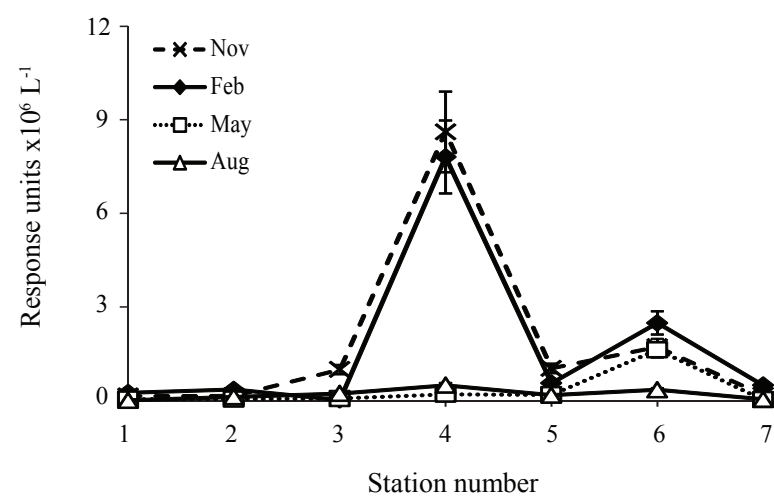

Fig. 2. The HPH crenarchaeol abundance along the sampling transect in (A) surface water and (B) bottom water.

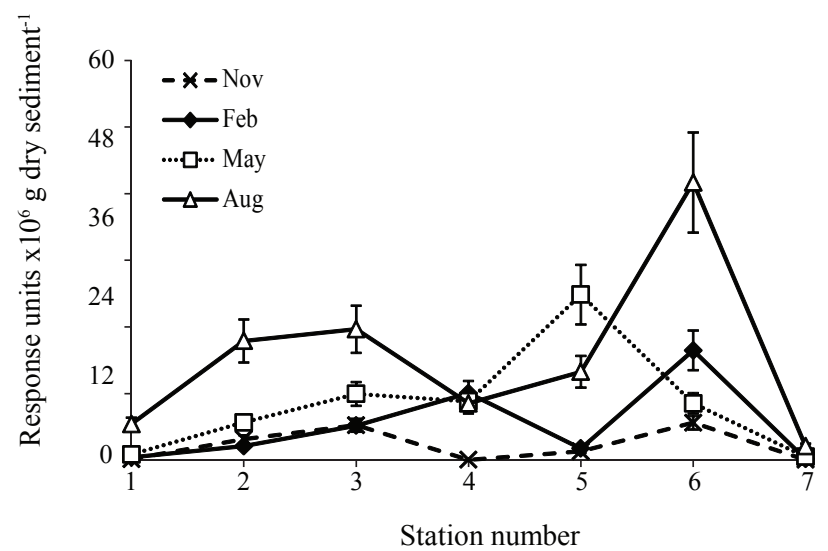

Fig. 3. The HPH crenarchaeol abundance along the sampling transect in the surface sediment.

\subsection{Thaumarchaeotal 16S rRNA gene abundance and transcriptional activity}

Thaumarchaeotal 16S rRNA gene abundance (DNA) could be measured in surface sediments (Fig. 4a) but was under the limit of detection in the surface waters (Fig. 4b). Thaumarchaeotal 16S rRNA gene abundance (DNA) was at least two orders of magnitude lower in sediment from station 1 in comparison with stations 4 and 6 . Thaumarchaeotal 16S rRNA 
Table 1. Chemical, biological, and physical properties of surface (S) and bottom (B) water of the southern North Sea.

\begin{tabular}{|c|c|c|c|c|c|c|c|c|c|c|c|c|c|c|}
\hline & \multirow{2}{*}{$\begin{array}{l}\text { Station } \\
\text { Depth* }\end{array}$} & \multicolumn{2}{|c|}{1} & \multicolumn{2}{|c|}{2} & \multicolumn{2}{|c|}{3} & \multicolumn{2}{|c|}{4} & \multicolumn{2}{|c|}{5} & \multicolumn{2}{|c|}{6} & \multirow{2}{*}{$\begin{array}{r}7 \\
\mathrm{M}\end{array}$} \\
\hline & & B & S & B & $\mathrm{S} \mid$ & B & S & B & S & B & S & B & S & \\
\hline Nov & Ammonium $(\mu \mathrm{M})$ & 1.00 & 0.84 & 2.69 & 1.51 & 1.04 & 1.04 & 0.77 & 0.55 & 0.14 & 0.12 & 0.98 & 1.21 & 5.24 \\
\hline \multirow[t]{7}{*}{2010} & Nitrate $(\mu \mathrm{M})$ & 0.4 & 0.4 & 0.7 & 0.5 & 0.8 & 0.8 & 1.1 & 1.4 & 4.1 & 4.0 & 2.3 & 2.2 & 9.0 \\
\hline & Nitrite $(\mu \mathrm{M})$ & 0.10 & 0.08 & 0.46 & 0.10 & 0.68 & 0.70 & 1.46 & 1.93 & 1.88 & 1.87 & 0.88 & 0.50 & 0.55 \\
\hline & Phosphate $(\mu \mathrm{M})$ & 0.24 & 0.22 & 0.30 & 0.24 & 0.30 & 0.33 & 0.42 & 0.47 & 0.46 & 0.45 & 0.33 & 0.27 & 0.36 \\
\hline & Silicate $(\mu \mathrm{M})$ & 0.1 & 0.1 & 2.6 & 2.6 & 3.3 & 3.4 & 4.4 & 4.3 & 4.9 & 4.8 & 2.8 & 2.2 & 8.1 \\
\hline & Temperature $\left({ }^{\circ} \mathrm{C}\right)$ & 8.9 & 8.9 & 9.8 & 9.8 & 10.2 & 10.2 & 10.3 & 10.3 & 10.3 & 10.2 & 10.1 & 9.9 & 7.9 \\
\hline & Salinity & 34.6 & 34.6 & 34.7 & 34.7 & 34.6 & 34.6 & 34.5 & 34.5 & 34.4 & 34.4 & 34.6 & 34.6 & 31.7 \\
\hline & Depth (m) & 27 & 2 & 42 & 2 & 42 & 2 & 45 & 2 & 38 & 2 & 33 & 2 & 2 \\
\hline Feb & Ammonium $(\mu \mathrm{M})$ & 0.31 & 0.30 & 0.96 & 1.03 & 0.08 & 0.09 & 0.25 & 0.29 & 0.04 & 0.04 & 0.12 & 0.11 & 5.11 \\
\hline \multirow[t]{7}{*}{2011} & Nitrate $(\mu \mathrm{M})$ & 3.7 & 3.7 & 3.0 & 2.8 & 5.4 & 5.4 & 6.2 & 6.1 & 7.4 & 7.4 & 8.7 & 8.7 & 39.0 \\
\hline & Nitrite $(\mu \mathrm{M})$ & 0.19 & 0.19 & 0.22 & 0.23 & 0.04 & 0.04 & 0.84 & 1.01 & 0.29 & 0.25 & 0.11 & 0.11 & 1.12 \\
\hline & Phosphate $(\mu \mathrm{M})$ & 0.38 & 0.39 & 0.34 & 0.32 & 0.48 & 0.48 & 0.42 & 0.41 & 0.49 & 0.50 & 0.58 & 0.57 & 0.71 \\
\hline & Silicate $(\mu \mathrm{M})$ & 2.0 & 2.0 & 2.7 & 2.5 & 5.0 & 5.1 & 4.4 & 4.3 & 5.0 & 4.8 & 5.0 & 5.0 & 22.4 \\
\hline & Temperature $\left({ }^{\circ} \mathrm{C}\right)$ & 5.2 & 5.2 & 4.6 & 4.6 & 5.5 & 5.5 & 5.0 & 5.0 & 5.1 & 5.1 & 5.0 & 5.0 & 4.9 \\
\hline & Salinity & 34.8 & 34.8 & 34.6 & 34.6 & 34.5 & 34.5 & 34.4 & 34.4 & 34.6 & 34.5 & 34.5 & 34.5 & 30.1 \\
\hline & Depth (m) & 24 & 2 & 39 & 2 & 41 & 2 & 43 & 2 & 37 & 2 & 32 & 2 & 2 \\
\hline May & Ammonium $(\mu \mathrm{M})$ & 0.15 & 0.08 & 0.09 & 0.09 & 0.17 & 0.10 & 0.87 & 0.34 & 0.32 & 0.28 & 0.84 & 0.55 & 2.25 \\
\hline \multirow[t]{7}{*}{2011} & Nitrate $(\mu \mathrm{M})$ & $>0.08$ & $>0.08$ & $>0.08$ & $>0.08$ & 1.0 & $>0.08$ & 1.7 & 0.1 & 0.1 & 0.1 & 0.1 & 0.1 & 3.1 \\
\hline & Nitrite $(\mu \mathrm{M})$ & 0.01 & 0.01 & 0.01 & 0.01 & 0.07 & 0.01 & 0.08 & 0.02 & 0.03 & 0.03 & 0.04 & 0.03 & 0.24 \\
\hline & Phosphate $(\mu \mathrm{M})$ & 0.09 & 0.09 & 0.07 & 0.07 & 0.17 & 0.06 & 0.10 & 0.03 & 0.05 & 0.05 & 0.07 & 0.07 & 0.09 \\
\hline & Silicate $(\mu \mathrm{M})$ & 0.4 & 0.4 & 1.6 & 1.5 & 1.7 & 0.5 & 2.3 & 0.8 & 1.4 & 1.4 & 1.4 & 1.1 & 1.1 \\
\hline & Temperature $\left({ }^{\circ} \mathrm{C}\right)$ & 11.4 & 11.5 & 10.4 & 10.7 & 6.5 & 10.7 & 8.6 & 10.5 & 11.9 & 11.9 & 12.1 & 12.1 & 14.0 \\
\hline & Salinity & 34.9 & 34.8 & 34.7 & 34.7 & 34.5 & 34.6 & 34.3 & 34.4 & 34.4 & 34.5 & 34.6 & 34.5 & 32.2 \\
\hline & Depth (m) & 24 & 2 & 41 & 2 & 43 & 2 & 44 & 2 & 38 & 2 & 33 & 2 & 2 \\
\hline Aug & Ammonium $(\mu \mathrm{M})$ & 0.10 & 0.12 & 0.37 & 0.11 & 1.34 & 0.08 & 0.94 & 0.08 & 0.52 & 0.07 & 1.36 & 0.52 & 0.26 \\
\hline \multirow[t]{7}{*}{2011} & Nitrate $(\mu \mathrm{M})$ & $>0.08$ & $>0.08$ & 0.3 & $>0.08$ & 0.9 & $>0.08$ & 0.2 & $>0.08$ & 0.1 & $>0.08$ & $>0.08$ & 0.1 & 0.1 \\
\hline & Nitrite $(\mu \mathrm{M})$ & $>0.01$ & $>0.01$ & 0.06 & $>0.01$ & 0.08 & 0.01 & 0.05 & 0.01 & 0.03 & 0.01 & 0.07 & 0.05 & 0.04 \\
\hline & Phosphate $(\mu \mathrm{M})$ & 0.04 & 0.03 & 0.35 & 0.05 & 0.32 & 0.09 & 0.27 & 0.14 & 0.22 & 0.18 & 0.29 & 0.21 & 0.04 \\
\hline & Silicate $(\mu \mathrm{M})$ & 1.0 & 0.9 & 6.2 & 0.5 & 5.7 & 1.5 & 3.6 & 2.1 & 3.2 & 3.0 & 3.5 & 4.5 & 0.4 \\
\hline & Temperature $\left({ }^{\circ} \mathrm{C}\right)$ & 15.4 & 15.5 & 9.0 & 16.0 & 13.3 & 16.1 & 15.4 & 16.3 & 16.2 & 16.8 & 16.9 & 17.3 & 18.3 \\
\hline & Salinity & 34.7 & 34.7 & 34.6 & 34.8 & 34.8 & 34.8 & 34.7 & 34.7 & 34.6 & 34.5 & 34.4 & 34.4 & 31.7 \\
\hline & Depth (m) & 26 & 2 & 43 & 2 & 43 & 2 & 45 & 2 & 38 & 2 & 34 & 2 & 2 \\
\hline
\end{tabular}

$* \mathrm{~B}=$ Bottom, $\mathrm{S}=$ Surface, $\mathrm{M}=\mathrm{Mid}$

Table 2. Geochemical properties and pore water composition of surface sediment $(0-1 \mathrm{~cm})$ at three stations in the North Sea during different seasons.

\begin{tabular}{|c|c|c|c|c|c|c|c|c|c|c|c|c|}
\hline & \multicolumn{4}{|c|}{ Station 1} & \multicolumn{4}{|c|}{ Station 4} & \multicolumn{4}{|c|}{ Station 7} \\
\hline & Nov & $\mathrm{Feb}$ & May & Aug & Nov & $\mathrm{Feb}$ & May & Aug & Nov & Feb & May & Aug \\
\hline Ammonium $(\mu \mathrm{M})$ & 2.9 & 7.4 & 2.3 & 4.5 & 6.0 & 3.1 & 8.7 & 11.4 & 8.2 & 6.2 & 10.2 & 14.5 \\
\hline Nitrate $(\mu \mathrm{M})$ & 5.3 & 22.3 & 8.7 & 14.7 & 18.0 & 16.9 & 20.3 & 8.4 & 21.9 & 44.2 & 11.8 & 6.8 \\
\hline Nitrite $(\mu \mathrm{M})$ & 0.30 & 0.32 & 0.36 & 0.46 & 0.45 & 0.23 & 0.42 & 0.90 & 0.45 & 0.57 & 1.5 & 1.7 \\
\hline Phosphate $(\mu \mathrm{M})$ & 1.0 & 1.5 & 1.9 & 3.9 & 1.4 & 1.5 & 1.7 & 1.4 & 1.3 & 1.0 & 1.5 & 0.9 \\
\hline Silicate $(\mu \mathrm{M})$ & 0.3 & 0.5 & 8.0 & 11.1 & 43.2 & 26.6 & 42.3 & 56.0 & 0.6 & 24.9 & 8.3 & 59.9 \\
\hline Median grain size $(\mu \mathrm{m})^{*}$ & \multicolumn{4}{|c|}{210} & \multicolumn{4}{|c|}{87} & \multicolumn{4}{|c|}{235} \\
\hline Silt and Clay $(<63 \mu \mathrm{m} ; \%)^{*}$ & \multirow{2}{*}{\multicolumn{4}{|c|}{$\begin{array}{c}0 \\
6.4\end{array}$}} & \multirow{2}{*}{\multicolumn{4}{|c|}{$\begin{array}{l}29.8 \\
48.0\end{array}$}} & \multicolumn{4}{|c|}{0} \\
\hline Very fine sand $(63-125 \mu \mathrm{m} ; \%)^{*}$ & & & & & & & & & \multicolumn{4}{|c|}{0.9} \\
\hline Fine sand $(125-250 \mu \mathrm{m} ; \%)^{*}$ & \multicolumn{4}{|c|}{62.6} & \multicolumn{4}{|c|}{22.5} & \multirow{2}{*}{\multicolumn{4}{|c|}{31.1}} \\
\hline Medium sand $(250-500 \mu \mathrm{m} ; \%)^{1}$ & \multicolumn{4}{|c|}{31.0} & \multicolumn{4}{|c|}{0} & & & & \\
\hline TOC $(\%)$ & \multicolumn{4}{|c|}{0.03} & \multicolumn{4}{|c|}{0.3} & \multicolumn{4}{|c|}{0.03} \\
\hline
\end{tabular}

* M. Le Guitton, personal communication, 2013.

gene abundance values were similar at stations 4 and 6 in August, while in February values at station 6 were twofold higher than at station 4. Expression of the thaumarchaeotal 16S rRNA gene was analyzed using reverse transcription (RT) followed by qPCR. In contrast to $16 \mathrm{~S}$ rRNA gene abundance, the thaumarchaeotal $16 \mathrm{~S}$ rRNA gene transcripts could be detected in the surface waters (Fig. 4b). Values for station 4 in February were high $\left(1.2 \times 10^{8}\right.$ thaumarchaeotal $16 \mathrm{~S}$ rRNA transcripts $\mathrm{L}^{-1}$ ) in comparison to station 1 $\left(2 \times 10^{5}\right.$ copies $\left.\mathrm{L}^{-1}\right)$ and station 6 (under detection limit). Thaumarchaeotal 16S rRNA gene transcript abundance in August was relatively low both at stations 4 and 6 (average of $8 \times 10^{2}$ copies $\mathrm{L}^{-1}$ ), while it was not detected in the surface water of station 1 . In the surface sediment, thaumarchaeotal 
16S rRNA gene transcript abundance was low at station 1 both in August and February (average of $3 \times 10^{4}$ copies $^{-1}$ ), while station 6 showed the highest values both in August and February (average of $2 \times 10^{7}$ copies $^{-1}$ ).

\subsection{Archaeal diversity}

To determine which members of the Archaea community were active, archaeal 16S rRNA genes were amplified and cloned from RNA extracted from stations 4 and 6 (surface water, February; surface sediment, August), which showed high thaumarchaeotal 16S rRNA gene abundance (Table 3). The recovered clones were mainly affiliated to the marine Thaumarchaeota group 1.1a (also known as Marine Group I; 42 to $94 \%$ ), and the group 1.2 (also known as C3, up to $48 \%$ ) (Fig. S2). Only a minor percentage of sequences were affiliated to other groups such as marine euryarchaeotal group II and unclassified groups (less than 10\%). The sequences attributed to Thaumarchaeota group 1.1a recovered from the clone libraries were diverse and closely affiliated to uncultured thaumarchaeotal 16S rRNA gene sequences previously detected in marine surface waters and marine sediments (Fig. S3a-f). Thaumarchaeotal 16S rRNA gene sequences recovered from stations 4 and 6 in surface waters (February) and surface sediments (August) were distributed throughout the Marine Group I clade. Several arbitrary subclusters (Fig. S3a-f) were defined based on grouping of the sequences recovered in this study. Subclusters 2, 3 and 4 included sequences amplified from both sediments and surface waters at different stations and in different seasons, while subclusters 1, 6 and 8 (included in the "Candidatus Nitrosopumilus" cluster) comprised sequences recovered only from surface waters with independence of the station sampled. In addition, subcluster 5 and 7 included sequences recovered from sediments also with no differentiation according the sampling station. Moreover, sequences from these subclusters were also closely related to Marine Group I thaumarchaeotal 16S rRNA gene sequences previously recovered either from surface waters or sediments.

\section{Discussion}

\subsection{Seasonal variability of Thaumarchaeota}

The seasonal variability in the surface waters, i.e. the higher HPH crenarchaeol abundance in November/February relative to May/August (Fig. 2a, b), is in agreement with findings from previous studies which have reported the highest concentrations of water column Thaumarchaeota in the North Sea in the winter months (Herfort et al., 2007; Pitcher et al., 2011b; Wuchter et al., 2006). This seasonality has also been observed in such diverse coastal environments as the northwestern Mediterranean Sea (Galand et al., 2010) and Antarctica (Murray et al., 1998). The similarity of the seasonality noted in the southern North Sea between this study and those of Herfort et al. (2007) and Wuchter et al. (2006), 7-8 yr previously, indicates that the seasonality in this region is a regular phenomenon. Herfort et al. (2007) proposed that for the southern North Sea this seasonality is governed by the availability of ammonia. Indeed, AOA have been shown to have a high affinity to ammonia (Martens-Habbena et al., 2009; Stahl and de la Torre, 2012). In spring and summer, phytoplankton use up the available ammonium until their growth is limited by nutrient availability. After their demise, due to e.g. light limitation in the winter, there is less competition for ammonium/ammonia as well as the remineralization of phytoplanktonic matter leading to ammonium release. While we did not report the phytoplankton cell numbers or chlorophyll $a$ concentration in this study, spring and summer blooms in the North Sea have been extensively described (e.g. Joint and Pomroy, 1993). Spearman rank correlations between nitrite and nitrate and the HPH crenarchaeol abundance were significant and positive ( $\rho=0.7$ and 0.6 respectively, both $P \leq$ $0.01)$. Nitrite is the product of the first step of the nitrification process (ammonium oxidation as is carried out by thaumarchaeotal ammonium-oxidizers) and nitrate is the product of the second step (nitrite oxidation carried out by nitriteoxidizing bacteria such as Nitrobacter). Hence, as products of the nitrification process, their concentrations do not provide information about the cause of thaumarchaeotal activity. The significant correlation between the concentration of silicate and the HPH abundance $(\rho=0.5, P \leq 0.01)$ is likely due to the fact that both are at their highest when phytoplankton numbers are low. Phosphate has been suggested to be one of the variables which plays a role in determining the thaumarchaeotal niches (Dang et al., 2013; Erguder et al., 2009), but from our data it cannot be established whether the correlation between phosphate and the HPH abundance ( $\rho=0.6$, $P \leq 0.01)$ is, as in the case of silicate, an indirect correlation or is a determining factor for the presence of Thaumarchaeota. The concentration of ammonium, which we surmise does have an effect on the abundance of Thaumarchaeota, exhibited the least strong, though still significant, correlation with the HPH abundance ( $\rho=0.4, P \leq 0.01)$. However, for a proper assessment of the relation between thaumarchaeotal abundance and nutrients, rate measurements rather than nutrient concentrations are needed (cf. Veuger et al., 2013).

In contrast to pelagic Thaumarchaeota, the abundance of the benthic Thaumarchaeota, as indicated by the HPH crenarchaeol, in the surface sediment $(0-1 \mathrm{~cm})$ was on average highest in the summer (August) and lowest in the winter (November). This may be expected because deposition of algal-bloom-derived organic matter onto the sediment takes place in late spring and summer and this deposited organic matter can be degraded, which results in the formation of ammonia (Thamdrup and Dalsgaard, 2008). Differences in pelagic and benthic Thaumarchaeota seasonality were supported by the thaumarchaeotal 16S rRNA gene transcriptional activity, which was generally higher in the summer in the surface sediments and higher in the winter in the surface 

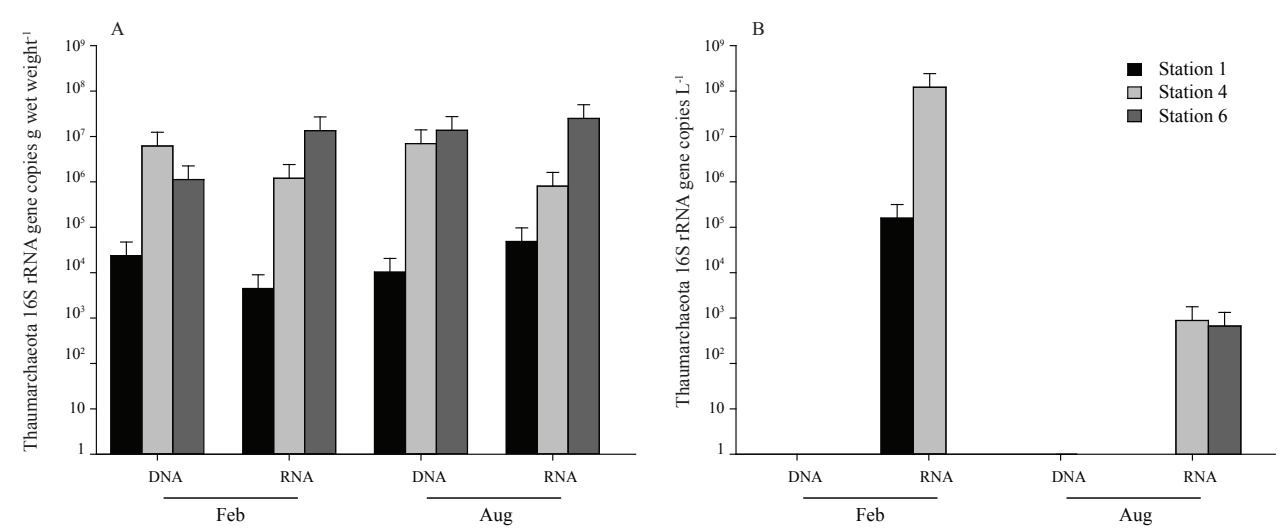

Fig. 4. Thaumarchaeota 16S rRNA gene copies (A) in surface sediment (g wet weight ${ }^{-1}$ ) and (B) in surface water $\left(\mathrm{L}^{-1}\right)$ from selected stations in February (Feb) and August (Aug). Logarithmic scale was used. Detection limit of the analysis, $220 \mathrm{copies}^{-1}$ and $30 \mathrm{copies}^{-1}$.

Table 3. Composition (\% of total clones sequenced) of archaeal 16S rRNA gene transcript clone libraries retrieved from stations 4 and 6 surface sediments from August 2010 and surface waters from February 2010.

\begin{tabular}{lllll}
\hline Archaeal groups & \multicolumn{2}{c}{ Surface water - February } & \multicolumn{2}{c}{ Sediment - August } \\
\cline { 2 - 5 } & Station 4 & Station 6 & Station 4 & Station 6 \\
\hline $\begin{array}{l}\text { Total number of clones sequenced } \\
\text { Unclassified }\end{array}$ & 61 & 69 & 83 & 83 \\
$\begin{array}{l}\text { Euryarchaeota } \\
\text { Marine euryarchaeota group II } \\
\text { Thaumarchaeota }\end{array}$ & $6 \%$ & & $8 \%$ & $8 \%$ \\
$\begin{array}{l}\text { Group 1.1a } \\
\text { Group 1.2 (C3) } \\
\text { Marine Benthic Group B }\end{array}$ & $5 \%$ & $6 \%$ & $3 \%$ & \\
\hline
\end{tabular}

water. This also supports the fact that the thaumarchaeotal biomarker HPH crenarchaeol is a good indicator of a living and dynamic community of Thaumarchaeota in these marine systems as it is correlated with the transcriptional activity.

The combination of IPL and genetic data in this and previous studies (Herfort et al., 2007; Pitcher et al., 2011a, b) has provided a strong basis for the ecological study of marine AOA in the southern North Sea. However, it should be noted that there are examples from this study where the lipid and genetic data do not always mirror each other. For example, in February the HPH abundance in the surface water was almost identical between stations 4 and 6 (Fig. 2). However, while the 16S rRNA gene expression was $1.2 \times 10^{8}$ copies $\mathrm{L}^{-1}$ at station 4 , it could not be detected at station 6 . This indicates that the HPH abundance at station 6 in February may have derived from dead or detrital thaumarchaeotal cells, a "fossil" signal. A fossil IPL signal may also play a role in the sediment: the higher levels of crenarchaeol IPLs at stations 2-6 may be due to the better preservation of organic matter in fine-grained sediment (Lengger et al., 2012). These differences suggest that there are different preservation processes, which play a role in the fate of IPLs and of nucleic acids.

\subsection{Spatial variability of Thaumarchaeota}

The spatial variability in HPH abundance in surface water is most evident in the November and February samples as they contain a wider range of HPH abundances. For example, stations 2 and 3 were less than $20 \mathrm{~km}$ apart, yet in both November and February they exhibited a substantial difference in HPH abundance (Fig. 2a). This result is similar to that of Herfort et al. (2007), who noted high levels of spatial variability in crenarchaeol core lipids, which indicates that the processes that control this spatial variability are a regular occurrence. In the present study, based on the February and November surface water HPH abundance, the transect can be divided into three sections: low at stations 1 and 2 , generally elevated at stations 3-6 and finally low at station 7 . This partitioning of the transect is comparable to the distribution of the different water masses present in the southern North Sea, which are particularly defined in the winter due to factors such as tidal action and outflows of the Rhine, Scheldt and Elbe rivers (Belkin et al., 2009). Several studies have described the shallow Dogger Bank region as an area with biological characteristics different from the surrounding 
regions of the North Sea (Kroncke and Knust, 1995). The water mass at the Dogger Bank has been described as having high rates of winter primary production (Howarth et al., 1993), which would potentially lead to higher levels of competition with phytoplankton for ammonia than in the other two sections of the transect. This may explain the low HPH abundance at stations 1 and 2 (Fig. 2a) and their low thaumarchaeotal 16S rRNA gene abundance and gene expression relative to station 4 (Fig. 4). Between stations 6 and 7 lies the Frisian Front (Belkin et al., 2009) between the central North Sea water (CNSW) and the continental coastal water (CCW), as is evident from the difference in salinity between these two stations at all times of the year (Table 1). We observed a distinct difference in the HPH abundance between the CCW side of the front (station 7) and the CNSW side of the front (stations 3, 4, 5, 6) (Fig. 2a). In contrast, van Duyl et al. (1990) observed higher bacterial abundance on the CCW side of the front than on the CNSW side (Van Duyl et al., 1990).

Between stations 3, 4, 5 and 6 the HPH abundances in surface water in November and February were relatively similar (Fig. 2a), corroborating that the four stations belonged to a single water mass. Phylogenetic analysis showed that differences between thaumarchaeotal 16S rRNA gene sequences of stations 4 and 6 were minimal (Fig. S3a-f), which discards the possibility of different thaumarchaeotal phylotypes in the CNSW. The difference in HPH abundance between the surface and bottom water in November and February (Fig. 2a, b) is relevant as the water column was well mixed at these times of the year (Table 1) and thus similar values would be expected. This difference could be due to resuspension of sediment, which has been shown to occur at stations 4 and 6 due to tidal currents and the actions of storms (Jones et al., 1998; Van Raaphorst et al., 1998). Furthermore, the high levels of benthic macrofauna we observed at station 6 (near the Frisian Front) and at station 4 (the Oyster Grounds) could have led to increased resuspension at the site (Rowden et al., 1998). This resuspension could deliver benthic Thaumarchaeota to the water column or could supply substrate to enrich the water column Thaumarchaeota. In fact, the possibility of transference of Thaumarchaeota diversity from the sediment to the surface water is supported by the phylogenetic analysis of thaumarchaeotal active diversity in the surface water and sediments of stations 4 and 6 in February and August, indicating that some thaumarchaeotal genotypes were found indistinctly in both settings (Fig. S3a-f). Alternatively, the increased bottom water Thaumarchaeota populations at stations 4 and 6 could be related to ammonium flux from the sediment. The Frisian Front region, in the area of station 6, has been shown in previous studies to be an area of notable ammonium flux from the sediment to the water column (Nedwell et al., 1993; Van Raaphorst et al., 1992). Furthermore, the flux of ammonium from the sediment to the bottom waters would be higher in spring and summer, and accordingly we observed that the bottom water HPH abundance was com- parable in May to that of November and February (although this did not extend to the August samples). Similarly, Herfort et al. (2007) observed increased concentrations of thaumarchaeotal core lipids, 16S rRNA gene abundance and thaumarchaeotal cell counts in April and August at the Frisian Front.

Spatial variability in the HPH abundance in the surface sediment (Fig. 3) was not as pronounced as that observed in the water column (Fig. 2a, b). However, station 6 did exhibit the highest HPH abundance, as well as gene abundance, most of the time compared to other stations. The high abundance of Thaumarchaeota at station 6 could be related to its position close to the Frisian Front. The Frisian Front is an area of high sedimentary deposition relative to other areas of the southern North Sea and is affected by deposition of particulate matter derived from the East Anglian turbidity plume (Eleveld et al., 2008), as well as phytodetritus from the overlying highly productive water column. It is the deposition of such organic matter that likely starts the process of ammonification, which would provide the ammonium to the porewater necessary for sedimentary nitrification to occur (Thamdrup and Dalsgaard, 2008). The relationship between the deposition of organic material and the level of benthic Thaumarchaeota is also evident at the opposite end of the abundance spectrum, at the sandy stations, 1 and 7, where the HPH abundance was generally lowest (Fig. 2a, b), as was 16S rRNA gene abundances of Thaumarchaeota (Fig. 4 and Table 3). Both stations had low organic carbon contents $(<0.05 \%)$ and large grain size (Table 2), which indicates coarse sediment areas with little organic matter deposition. Indeed the North Sea as a whole has very few areas of permanent deposition due to high levels of lateral particle transport (Eisma, 1981).

\section{Conclusions}

We have used a crenarchaeol intact polar lipid in combination with thaumarchaeotal 16S rRNA gene abundance to examine the distribution of Thaumarchaeota in the southern North Sea. In the water column we found a higher abundance of Thaumarchaeota in the winter season than in the summer. This study was extended to the sediment, where we found that Thaumarchaeota were more abundant in spring and summer. This novel observation corresponds well with the idea that ammonia availability is a key factor in thaumarchaeotal niche determination. Spatial variability in HPH crenarchaeol, thaumarchaeotal 16S rRNA gene abundance and transcriptional activity was observed in the surface waters, corresponding well with the different water masses present. In bottom waters we observed differences in thaumarchaeotal abundance to the surface, which may be related to suspension of benthic Thaumarchaeota to the water column or due to delivery of e.g. resuspended sediment or ammonium to the water column, which could be utilized by pelagic Thaumarchaeota. 


\section{Supplementary material related to this article is available online at http://www.biogeosciences.net/10/ 7195/2013/bg-10-7195-2013-supplement.pdf.}

Acknowledgements. We thank the captains and crew of the R/V Pelagia for their support during the four cruises. We thank the MTE and MTM departments (NIOZ) for technical support onboard and J. van Ooijen and S. Ossebaar for nutrient sample collection and analysis. We thank colleagues from the BGC lab (NIOZ) for assistance with lipid and DNA/RNA sample collection, sediment slicing and porewater sample collection. We also thank the NICYCLE project coordinator Lucas Stal and project partners for their collaboration as well as Marie Le Guitton for collecting and sharing grain size data. This study is part of the NICYCLE project supported by the Netherlands Organisation for Scientific Research (NWO) through grant 839.08.331 to J. S. Sinninghe Damsté. We also thank one anonymous reviewer and R. Hansman and for constructive edits and helpful suggestions in the review process as well as M. Tiessen for helpful discussions during the revision of this manuscript. All the data used in this manuscript is archived and available at http://doi.pangaea.de/10.1594/PANGAEA.821656.

Edited by: G. Herndl

\section{References}

Agogue, H., Brink, M., Dinasquet, J., and Herndl, G. J.: Major gradients in putatively nitrifying and non-nitrifying Archaea in the deep North Atlantic, Nature, 456, 788-791, 2008.

Alonso-Sáez, L., Waller, A. S., Mende, D. R., Bakker, K., Farnelid, H., Yager, P. L., Lovejoy, C., Tremblay, J.-É., Potvin, M., Heinrich, F., Estrada, M., Riemann, L., Bork, P., Pedrós-Alió, C., and Bertilsson, S.: Role for urea in nitrification by polar marine Archaea, Proc. Natl. Acad. Sci. USA, 109, 17989-17994, 2012.

Belkin, I. M., Cornillon, P. C., and Sherman, K.: Fronts in Large Marine Ecosystems, Prog. Oceanogr., 81, 223-236, 2009.

Beman, J. M., Popp, B. N., and Alford, S. E.: Quantification of ammonia oxidation rates and ammonia-oxidizing archaea and bacteria at high resolution in the Gulf of California and eastern tropical North Pacific Ocean, Limnol. Oceanogr., 57, 711-726, 2012.

Bernhard, A. E., Landry, Z. C., Blevins, A., de la Torre, J. R., Giblin, A. E., and Stahl, D. A.: Abundance of Ammonia-Oxidizing Archaea and Bacteria along an Estuarine Salinity Gradient in Relation to Potential Nitrification Rates, Appl. Environ. Microbiol., 76, 1285-1289, 2010.

Brochier-Armanet, C., Boussau, B., Gribaldo, S., and Forterre, P.: Mesophilic crenarchaeota: proposal for a third archaeal phylum, the Thaumarchaeota, Nat. Rev. Microbiol., 6, 245-252, 2008.

Buckles, L. K., Villanueva, L., Weijers, J. W. H., Verschuren, D., and Sinnighe Damsté, J. S. : Linking isoprenoidal GDGT membrane lipid distributions with gene abundances of ammoniaoxidizing Thaumarchaeota and uncultured crenarchaeotal groups in the water column of a tropical lake (Lake Challa, East Africa), Environ. Microbiol., 15, 2445-2462, doi:10.1111/14622920.12118, 2013.
Coolen, M. J. L., Abbas, B., van Bleijswijk, J., Hopmans, E. C., Kuypers, M. M. M., Wakeham, S. G., and Sinninghe Damsté, J. S.: Putative ammonia-oxidizing Crenarchaeota in suboxic waters of the Black Sea: a basin-wide ecological study using $16 \mathrm{~S}$ ribosomal and functional genes and membrane lipids, Environ. Microbiol., 9, 1001-1016, 2007.

Creutzberg, F.: Distribution patterns of two bivalve species (Nucula turgida, Tellina fabula) along a frontal system in the Southern North Sea, Neth. J. Sea Res., 20, 305-311, 1986.

Dang, H., Zhou, H., Yang, J., Ge, H., Jiao, N., Luan, X., Zhang, C., and Klotz, M. G.: Thaumarchaeotal signature gene distribution in sediments of the northern South China Sea - an indicator for the metabolic intersection of the marine carbon, nitrogen and phosphorus cycles?, Appl. Environ. Microbiol., 79, 2137-2147, 2013.

DeLong, E.: Archaea in Coastal Marine Environments, Proc. Natl. Acad. Sci. USA, 89, 5685-5689, 1992.

Eisma, D.: Supply and Deposition of Suspended Matter in the North Sea, in: Holocene Marine Sedimentation in the North Sea Basin, edited by: Nio, S.-D., Shüttenhelm, R. T. E., and Weering, T. C. E. V., 415-428, Blackwell Publishing Ltd., Oxford, 1981.

Eleveld, M. A., Pasterkamp, R., van der Woerd, H. J., and Pietrzak, J. D.: Remotely sensed seasonality in the spatial distribution of sea-surface suspended particulate matter in the southern North Sea, Estuar. Coast. Shelf S., 80, 103-113, 2008.

Erguder, T. H., Boon, N., Wittebolle, L., Marzorati, M., and Verstraete, W.: Environmental factors shaping the ecological niches of ammonia-oxidizing archaea, Fems Microbiol. Rev., 33, 855869, 2009.

Francis, C. A., Beman, J. M., and Kuypers, M. M. M.: New processes and players in the nitrogen cycle: the microbial ecology of anaerobic and archaeal ammonia oxidation, ISME J., 1, 1927, 2007.

Galand, P. E., Gutierrez-Provecho, C., Massana, R., Gasol, J. M., and Casamayor, E. O.: Inter-annual recurrence of archaeal assemblages in the coastal NW Mediterranean Sea (Blanes Bay Microbial Observatory), Limnol. Oceanogr., 55, 2117-2125, 2010.

Gattuso, J. P., Frankignoulle, M., and Wollast, R.: Carbon and carbonate metabolism in coastal aquatic ecosystems, Annu. Rev. Ecol. Syst., 29, 405-434, 1998.

Gruber, N.: Chapter 1 - The Marine Nitrogen Cycle: Overview and Challenges, in Nitrogen in the Marine Environment (2nd Edition), 1-50, Academic Press, San Diego, 2008.

Hansman, R. L., Griffin, S., Watson, J. T., Druffel, E. R. M., Ingalls, A. E., Pearson, A., and Aluwihare, L. I.: The radiocarbon signature of microorganisms in the mesopelagic ocean, Proc. Natl. Acad. Sci. USA, 106, 6513-6518, 2009.

Herfort, L., Schouten, S., Abbas, B., Veldhuis, M. J. W., Coolen, M. J. L., Wuchter, C., Boon, J. P., Herndl, G. J., and Sinninghe Damsté, J. S.: Variations in spatial and temporal distribution of Archaea in the North Sea in relation to environmental variables, FEMS Microbiol. Ecol., 62, 242-257, 2007.

Herndl, G. J., Reinthaler, T., Teira, E., van Aken, H., Veth, C., Pernthaler, A., and Pernthaler, J.: Contribution of Archaea to total prokaryotic production in the deep Atlantic Ocean, Appl. Environ. Microbiol., 71, 2303-2309, 2005.

Holmes, D. E., Nevin, K. P., and Lovley, D. R.: In situ expression of nifD in Geobacteraceae in subsurface sediments, Appl. Environ. Microbiol., 70, 7251-7259, 2004. 
Howarth, M., Dyer, K., Joint, I., Hydes, D., Purdie, D., Edmunds, H., Jones, J., Lowry, R., Moffat, T., Pomroy, A., and Proctor, R.: Seasonal Cycles and Their Spatial Variability, Philos. Tr. R. Soc. S.-A., 343, 383-403, 1993.

Ingalls, A. E., Shah, S. R., Hansman, R. L., Aluwihare, L. I., Santos, G. M., Druffel, E. R. M., and Pearson, A.: Quantifying archaeal community autotrophy in the mesopelagic ocean using natural radiocarbon, Proc. Natl. Acad. Sci. USA, 103, 6442-6447, 2006.

Jenkyns, H. C., Schouten-Huibers, L., Schouten, S., and Sinninghe Damsté, J. S.: Warm Middle Jurassic-Early Cretaceous high-latitude sea-surface temperatures from the Southern Ocean, Clim. Past, 8, 215-226, doi::10.5194/cp-8-215-2012, 2012.

Joint, I. and Pomroy, A.: Phytoplankton Biomass and Production in the Southern North-Sea, Mar. Ecol.-Prog. Ser., 99, 169-182, 1993.

Jones, S. E., Jago, C. F., Bale, A. J., Chapman, D., Howland, R. J. M., and Jackson, J.: Aggregation and resuspension of suspended particulate matter at a seasonally stratified site in the southern North Sea: physical and biological controls, Cont. Shelf Res., 18, 1283-1309, 1998.

Karner, M. B., DeLong, E. F., and Karl, D. M.: Archaeal dominance in the mesopelagic zone of the Pacific Ocean, Nature, 409, 507510,2001

Könneke, M., Bernhard, A. E., de la Torre, J. R., Walker, C. B., Waterbury, J. B., and Stahl, D. A.: Isolation of an autotrophic ammonia-oxidizing marine archaeon, Nature, 437, 543-546, 2005.

Kroncke, I. and Knust, R.: The Dogger-Bank - a Special Ecological Region in the Central North-Sea, Helgolander. Meeresun., 49, 335-353, 1995.

Lengger, S. K., Hopmans, E. C., Reichart, G.-J., Nierop, K. G. J., Sinninghe Damsté, J. S., and Schouten, S.: Intact polar and core glycerol dibiphytanyl glycerol tetraether lipids in the Arabian Sea oxygen minimum zone. Part II: Selective preservation and degradation in sediments and consequences for the TEX 86 , Geochim. Cosmochim. Ac., 98, 244-258, 2012.

Ludwig, W., Strunk, O., Westram, R., Richter, L., Meier, H., Yadhukumar, Buchner, A., Lai, T., Steppi, S., Jobb, G., Förster, W., Brettske, I., Gerber, S., Ginhart, A. W., Gross, O., Grumann, S., Hermann, S., Jost, R., König, A., Liss, T., Lüßmann, R., May, M., Nonhoff, B., Reichel, B., Strehlow, R., Stamatakis, A., Stuckmann, N., Vilbig, A., Lenke, M., Ludwig, T., Bode, A., and Schleifer, K.-H.: ARB: a software environment for sequence data, Nucleic Acids Res., 32, 1363-1371, 2004.

Martens-Habbena, W., Berube, P. M., Urakawa, H., de la Torre, J. R., and Stahl, D. A.: Ammonia oxidation kinetics determine niche separation of nitrifying Archaea and Bacteria, Nature, 461, 976-979, 2009.

Mosier, A. C. and Francis, C. A.: Relative abundance and diversity of ammonia-oxidizing archaea and bacteria in the San Francisco Bay estuary, Environ. Microbiol., 10, 3002-3016, 2008.

Murray, A. E., Preston, C. M., Massana, R., Taylor, L. T., Blakis, A., Wu, K., and DeLong, E. F.: Seasonal and spatial variability of bacterial and archaeal assemblages in the coastal waters near Anvers Island, Antarctica, Appl. Environ. Microbiol., 64, 25852595, 1998.

Nedwell, D., Parkes, R., Upton, A., and Assinder, D.: Seasonal Fluxes Across the Sediment-Water Interface, and Processes Within Sediments, Philos. Tr. R. Soc. S.-A., 343, 519-529, 1993.
Ouverney, C. C. and Fuhrman, J. A.: Marine Planktonic Archaea Take Up Amino Acids, Appl. Environ. Microbiol., 66, 48294833, 2000.

Park, B.-J., Park, S.-J., Yoon, D.-N., Schouten, S., Sinninghe Damsté, J. S., and Rhee, S.-K.: Cultivation of Autotrophic Ammonia-Oxidizing Archaea from Marine Sediments in Coculture with Sulfur-Oxidizing Bacteria, Appl. Environ. Microbiol., 76, 7575-7587, 2010.

Pearson, A., McNichol, A. P., Benitez-Nelson, B. C., Hayes, J. M., and Eglinton, T. I.: Origins of lipid biomarkers in Santa Monica Basin surface sediment: A case study using compound-specific Delta C-14 analysis, Geochim. Cosmochim. Ac., 65, 3123-3137, 2001.

Pitcher, A., Villanueva, L., Hopmans, E. C., Schouten, S., Reichart, G.-J., and Sinninghe Damsté, J. S.: Niche segregation of ammonia-oxidizing archaea and anammox bacteria in the Arabian Sea oxygen minimum zone, ISME J., 5, 1896-1904, 2011 a.

Pitcher, A., Wuchter, C., Siedenberg, K., Schouten, S., and Sinninghe Damsté, J. S.: Crenarchaeol tracks winter blooms of ammonia-oxidizing Thaumarchaeota in the coastal North Sea, Limnol. Oceanogr., 56, 2308-2318, 2011 b.

Quast, C., Pruesse, E., Yilmaz, P., Gerken, J., Schweer, T., Yarza, P., Peplies, J., and Glöckner, F. O.: The SILVA ribosomal RNA gene database project: improved data processing and web-based tools, Nucleic Acids Res., 41, 590-596, 2013.

Rowden, A. A., Jago, C. F., and Jones, S. E.: Influence of benthic macrofauna on the geotechnical and geophysical properties of surficial sediment, North Sea, Cont. Shelf Res., 18, 1347-1363, 1998.

Sahan, E. and Muyzer, G.: Diversity and spatio-temporal distribution of ammonia-oxidizing Archaea and Bacteria in sediments of the Westerschelde estuary, FEMS Microbiol. Ecol., 64, 175-186, 2008.

Sakami, T.: Distribution of Ammonia-Oxidizing Archaea and Bacteria in the Surface Sediments of Matsushima Bay in Relation to Environmental Variables, Microbes Environ., 27, 61-66, 2012.

Schouten, S., Hopmans, E. C., Baas, M., Boumann, H., Standfest, S., Könneke, M., Stahl, D. A., and Sinninghe Damsté, J. S.: Intact Membrane Lipids of "Candidatus Nitrosopumilus maritimus," a Cultivated Representative of the Cosmopolitan Mesophilic Group I Crenarchaeota, Appl. Environ. Microbiol., 74, 24332440, 2008.

Schouten, S., Hopmans, E. C., and Sinninghe Damsté, J. S.: The organic geochemistry of glycerol dialkyl glycerol tetraether lipids: A review, Org. Geochem., 54, 19-61, 2013.

Stahl, D. A. and de la Torre, J. R.: Physiology and Diversity of Ammonia-Oxidizing Archaea, Annu. Rev. Microbiol., 66, 83101, 2012.

Sturt, H. F., Summons, R. E., Smith, K., Elvert, M., and Hinrichs, K. U.: Intact polar membrane lipids in prokaryotes and sediments deciphered by high-performance liquid chromatography/electrospray ionization multistage mass spectrometry - new biomarkers for biogeochemistry and microbial ecology, Rapid Commun. Mass Sp., 18, 617-628, 2004.

Teira, E., Reinthaler, T., Pernthaler, A., Pernthaler, J., and Herndl, G. J.: Combining Catalyzed Reporter Deposition-Fluorescence In Situ Hybridization and Microautoradiography To Detect Substrate Utilization by Bacteria and Archaea in the Deep Ocean, Appl. Environ. Microbiol., 70, 4411-4414, 2004. 
Teira, E., van Aken, H., Veth, C., and Herndl, G. J.: Archaeal uptake of enantiomeric amino acids in the meso- and bathypelagic waters of the North Atlantic, Limnol. Oceanogr., 51, 60-69, 2006.

Thamdrup, B. and Dalsgaard, T.: Nitrogen Cycling in Sediments, in: Microbial Ecology of the Oceans, edited by: Kirchman, D. L., 527-568, John Wiley \& Sons, Inc., Hoboken, 2008.

Van Duyl, F. C., Bak, R. P. M., Kop, A. J., and Nieuwland, G.: Bacteria, auto- and heterotrophic nanoflagellates, and their relations in mixed, frontal and stratified waters of the North Sea, Neth. J. Sea Res., 26, 97-109, 1990.

Van Raaphorst, W., Kloosterhuis, H. T., Berghuis, E. M., Gieles, A. J. M., Malschaert, J. F. P., and Van Noort, G. J.: Nitrogen cycling in two types of sediments of the Southern North Sea (Frisian front, broad fourteens): field data and mesocosm results, Neth. J. Sea Res., 28, 293-316, 1992.

Van Raaphorst, W., Malschaert, H., and Van Haren, H.: Tidal resuspension and deposition of particulate matter in the Oyster Grounds, North Sea, J. Mar. Res., 56, 257-291, 1998.

Veuger, B., Pitcher, A., Schouten, S., Sinninghe Damsté, J. S., and Middelburg, J. J.: Nitrification and growth of autotrophic nitrifying bacteria and Thaumarchaeota in the coastal North Sea, Biogeosciences, 10, 1775-1785, doi:10.5194/bg-10-1775-2013, 2013.
Weston, K., Fernand, L., Nicholls, J., Marca-Bell, A., Mills, D., Sivyer, D., and Trimmer, M.: Sedimentary and water column processes in the Oyster Grounds: A potentially hypoxic region of the North Sea, Mar. Environ. Res., 65, 235-249, 2008.

White, D., Davis, W., Nickels, J., King, J., and Bobbie, R.: Determination of the Sedimentary Microbial Biomass by Extractable Lipid Phosphate, Oecologia, 40, 51-62, 1979.

Wuchter, C., Schouten, S., Boschker, H. T. S., and Sinninghe Damsté, J. S.: Bicarbonate uptake by marine Crenarchaeota, FEMS Microbiol. Lett., 219, 203-207, 2003.

Wuchter, C., Abbas, B., Coolen, M. J. L., Herfort, L., van Bleijswijk, J., Timmers, P., Strous, M., Teira, E., Herndl, G. J., Middelburg, J. J., Schouten, S., and Sinninghe Damsté, J. S.: Archaeal nitrification in the ocean, Proc. Natl. Acad. Sci. USA, 103, 12317-12322, 2006. 